Edel Karin Kvam

Universitetet i Bergen

DOI: http://dx.doi.org/10.5617/adno.6248

\title{
Praksisveiledning og lærerstudenters profesjonelle utvikling Om utviklende kunnskapsprosesser i lærerutdanningens praksisveiledning
}

\section{Sammendrag}

I denne artikkelen argumenterer jeg for at praksisveiledning kan bidra til lererstudenters profesjonelle utvikling, men også at dette bare er en mulighet som må gripes for å realiseres. Norsk og internasjonal lcererutdanningsforskning viser et mangfold av veiledningspraksiser i studentenes praksisperioder. Likevel er det noen felles kjennetegn ved veiledningen studentene tilbys. Forskning viser at praksisveiledning er knyttet til utførelse av spesifikke handlinger, og at veiledere i mindre grad inviterer til drøfting av studentenes intensjoner og mål for den pedagogiske virksomheten. Veiledere gir råd og fremstår som eksperter på undervisningssituasjoner, fremfor å søke dypere refleksjon. På grunnlag av veilednings- og profesjonsteori, sett $i$ relasjon til tidligere larerutdanningsforskning, argumenterer jeg for at praksisveiledning kan tjene på $ø k t$ bevissthet om samtalekvaliteter. Artikkelen viser hvordan fenomener som å be om begrunnelser for handling, yte motstand på begrunnelser og å etablere reelt samarbeid mellom studenter og veiledere om hvordan praksis kan forstås, er forutsetninger for at profesjonsutviklende kunnskapsprosesser kan finne sted.

Nøkkelord: lererutdanning, praksisveiledning, profesjonell utvikling, kunnskapsprosesser

\section{Placement mentoring and student teacher' professional development}

\begin{abstract}
In this article I argue that mentoring can contribute to teaching students' professional development, but also that this is just an opportunity that must be grasped in order to be realised. Norwegian and international teacher education research shows a diversity of placement mentoring practices during students' placement periods. Nevertheless, there are some characteristics common across all mentoring offered to students. Research shows that mentoring is being connected to the completion of specific actions, and that mentors to a lesser extent
\end{abstract}


invite to discuss the students' intentions and aims for the educational activity. Mentors generally offers advice and acts as experts in teaching situations rather than promoting deeper reflection. Based on theories of mentoring and professions, in relations to previous teacher education research, I argue that placement mentoring may benefit from increased awareness of conversation qualities. The article demonstrates how phenomena such as asking for justifications for actions, providing opposition to justifications and establishing real cooperation between students and mentors on how teaching practice can be understood are all prerequisites for professional development knowledge processes being able to take place.

Keywords: Teacher education, placement mentoring, professional development, knowledge processes

\section{Innledning}

Profesjonsutdanning er å kvalifisere for arbeid innenfor et spesifikt yrkesfelt (Smedby og Mausethagen, 2017), i denne artikkelen med fokus på lærerutdanningene. Å kvalifisere til yrkesutøvelse handler om å innvie studentene i profesjonens kunnskaper og praksisformer. En slik innvielse gir grunnlag for å kunne foreta relevante valg i ulike yrkessituasjoner, og for å kunne handle i tråd med profesjonens normer og verdier (Nerland og Hermansen, 2017). Når lærerstudentene har gjennomført kvalifisering gjennom utdanning vil de møte en skoleorganisasjon i stadig endring. Det utvikles og vedtas nye skolereformer i takt med samfunnsutviklingen, og med det følger også en lærerrolle i endring (Dahl mfl., 2016; Mausethagen, 2015). Lærerutdanningen skal i dette perspektivet ikke bare gi grunnlag for å mestre overgangen til yrket, men også gi grunnlag for at lærere over tid kan mestre et yrke i utvikling. En betydelig kjerne for kvalifiseringen vil derfor være å «ruste for kontinuerlig profesjonell utvikling» (Kunnskapsdepartementet, 2016a og b §1). ${ }^{1}$ Det ligger altså til lærerens oppgave å videreutvikle sin praksis (Kunnskapsdepartementet, 2017).

Profesjonskvalifisering i utdanning foregår på flere arenaer. Artikkelen drøfter praksisveiledning som arena for lærerkvalifisering. Sentralt i lærerutdanningene, nasjonalt som internasjonalt, er perioder med sammenhengende øving i praktisk arbeid, hvor det stilles krav om at studenter skal motta veiledning ${ }^{2}$ (For Norges del, se Kunnskapsdepartementet, 2013, § 3; 2015, §3; 2016a, §3 og 2016b §3).

\footnotetext{
${ }^{1}$ Ordlyden er hentet fra forskrift om grunnskolelærerutdanningen. Tilsvarende formuleringer om at utdanningen skal ruste for utviklingskompetanse finner vi også i forskrifter for lektorutdanning (jf. Kunnskapsdepartementet, 2013) og Praktisk-pedagogisk utdanning (PPU) (jf. Kunnskapsdepartementet, 2015).

${ }^{2}$ Praksis skal være både veiledet og vurdert. Vurderingens funksjon i praksisopplæringen er både summativ og formativ, og vurderingens formative funksjon kan forstås som del av veiledningens funksjon (Bjerkholt, 2017; Tillema, Smith og Leshem, 2011; Skagen og Smith, 2018). Jeg forholder meg til veiledning som begrep i denne artikkelen, og går ikke nærmere inn på forholdet mellom veiledning og vurdering.
} 
Fra nasjonalt hold stilles det imidlertid ingen krav til praksisveiledningens innhold, verken i forskrifter eller i retningslinjer for utdanningene. Dette kan tolkes som at veiledning forstås som et gode i seg selv, uavhengig av dens kvaliteter. Et sentralt spørsmål blir hvordan valg av innhold i praksisveiledningen, så vel som hvilken form den har, kan være av betydning for lærerstudentenes profesjonelle utvikling.

\section{Forskningsspørsmål og sentrale begreper}

I denne artikkelen vil jeg diskutere profesjonskvalifisering i lærerutdanning med utgangspunkt i følgende forskningsspørsmål: Hvordan kan praksisveiledning som avtalte samtaler $i$ undervisningens for- og/eller etterarbeid bidra til lcererstudentenes profesjonelle utvikling? Med utgangspunkt i empirisk forskning på praksisveiledning i lærerutdanningen, og på grunnlag av veilednings- og profesjonsteori, er ambisjonen å gjennom en drøfting av praksisveiledningens muligheter og begrensninger, og identifisere fenomener som kan, og kanskje bør, gjøres til gjenstand for nye empiriske studier. Artikkelen bygger altså ikke på egen empiri, men fører teoretiske argument på grunnlag av en bred sammenstilling av litteratur. I praksisveiledning inngår også veileder fra Universitets- og høgskolesektoren, men jeg avgrenser praksisveiledning her til å gjelde den veiledning som foregår mellom praksisveileder fra praksisskolen og student. ${ }^{3}$

Med uttrykket profesjonell utvikling i forskningsspørsmålet forstås tilegnelse av og endring i kunnskap og kompetanse, noe som fordrer en aktiv kunnskaps- og erfaringssøkende holdning hos yrkesutøver (Rønning, 2008). Jeg støtter meg på Havnes og Smedby (2014) sin forskning i det profesjonell utvikling behandles i diskusjonen som en prosess, nærmere bestemt som en «on-going aspect of professional careers, starting in professional education, but continuing during the professonal career - perhaps accelerating, taking new directions or reaching another level - as the person enters the field or professional practice» (s. 916). Praksisveiledning i lærerutdanningene kan foregå gjennom observasjon, samhandling og samtaler, i spennet mellom tradisjoner fra mesterlære (Nielsen og Kvale, 1999) til refleksjon over handling (Handal og Lauvås, 1999). Avgrensningen i forskningsspørsmålet, hvor diskusjonen forholder seg til samtaler i undervisningens for- og/eller etterarbeid, innebærer en særlig oppmerksomhet om bakenforliggende rasjonale for handlinger sett opp mot profesjonell utvikling. ${ }^{4}$ I veiledningssamtaler som foregår i undervisningens forog/eller etterarbeid finnes det bedre vilkår for å arbeide med intensjoner for handlinger, enn hva som vil være tilfelle under studentenes øving på den delen av

\footnotetext{
${ }^{3}$ For videre lesning om praksisveiledning der alle tre aktørene inngår se f. eks. Eide, Brekke og Holthe (2017) og Lillejord og Børte (2014).

${ }^{4}$ Dale (1989; 1999) knytter denne virksomheten til læreres andre- (K2) og tredje kompetansenivå (K3). Han argumenterer for at pedagogisk profesjonalitet fordres av at det utvikles et komplementært samspill mellom læreres ulike kompetansenivåer. Det må med andre ord etableres en innvendig relasjon mellom å gjennomføre undervisning (K1), å bygge opp eller konstruere undervisningsprogrammer (K2) og å kommunisere i, og selv utvikle, didaktisk teori (K3).
} 
undervisning som skjer sammen med elevene. Dette fordi undervisning kan være preget av handlingstvang, i betydning av at studenter må overveie og beslutte hva som skal gjøres i øyeblikket. Handlingstvang fordrer ifølge Dale (1993) følgelig raske avgjørelser og svekker muligheter for refleksjon, også kalt indre handlinger. Dermed forringes lærerens rasjonalitet. Utenfor handlingstvangen, eksempelvis i undervisningens for- og/eller etterarbeid, finnes derimot muligheter for refleksjon over et større spekter av handlingsalternativer og de ulike alternativenes rasjonalitet. Studier av profesjonsutøvere viser at nettopp det å opprettholde kontinuerlig refleksjon i møte med arbeidets utfordringer og kompleksitet er det mest sentrale enkeltstående aspekt ved profesjonell utvikling (Rønnestad, 2008). Jeg vil derfor mer inngående undersøke hvordan reflekterende dialoger i kontekst av praksisveiledning kan påvirke muligheter for profesjonell utvikling. En grunnleggende antakelse er at det ikke er tilstrekkelig å opprettholde reflekterende samtaler, om ikke refleksjonene fremmer kunnskapsprosesser.

Det er naturligvis en rekke faktorer ved veiledningen som virker bestemmende for om potensialet for profesjonell utvikling blir brukt. Det lar seg ikke gjøre å uttegne et klart avgrenset skille mellom når praksisveiledning bidrar til profesjonell utvikling, og når det ikke gjør det. For at veiledning kan tjene studentenes profesjonelle utvikling fordres et sammensatt samspill mellom praksislærer og student, innvevd i muligheter og begrensninger som er gitt ved den sammenhengen opplæringen skjer i. Praksisveiledning er, som all veiledning, dypt relasjonell i sin karakter og betinget av en sosial, kulturell og historisk sammenheng som definerer og setter grenser for veiledningens form og innhold (Orland-Barak, 2014; Skagen, 2013). Samtidig vil jeg gjennom diskusjonen i denne artikkelen belyse hvordan veiledningssamtaler kan være av ulik kvalitet, hvordan de kan være gode og mindre gode målt ut fra profesjonell utvikling.

Innledningsvis skisseres status innen den empiriske forskningen om forholdet mellom praksisveiledning og profesjonell utvikling i lærerutdanningene, nasjonalt som internasjonalt. Hensikten er å identifisere kjennetegn ved veiledning $\mathrm{i}$ praksis. Mot den bakgrunn, og med støtte i veilednings- og profesjonsteori, fører jeg frem tre argument. Først følger en argumentasjon for at muligheter for studentenes profesjonelle utvikling finnes ved at det under veiledningen aktivt bes om begrunnelser for handlinger, dernest at det gis motstand på de begrunnelsene som gis, før jeg avslutningsvis diskuterer betydningen av at student og praksislærer samarbeider om kunnskapsutvikling for god praksis.

\section{Empirisk forskning på praksisveiledning i lærerutdanningene}

Norsk og internasjonal empirisk forskning innen lærerutdanning viser et mangfold av ulike veiledningspraksiser i studentenes praksisperioder. Dette illustreres i en nyere norsk studie om hva lærerstudenter lærer i praksis, der Ulvik (mfl., 2017) presenterer data hvor det kommer frem ulike erfaringer med den veiledningen som foregår. Mens noen praksisveiledere bestreber seg på å fremme dialog og oppmuntrer studentene til å selv prøve ut ulike måter å undervise på, er 
andre praksisveiledere mer tilbøyelige til å fortelle studentene hva de skal gjøre og ikke gjøre i praksis. I slike tilfeller opptrer veilederne som om de vet best, og forstår sin rolle som eksperter på feltet. «I felt that he tried to make me like him», forteller en student om sin praksisveileder (Ulvik mfl., 2017, s. 644. Se også Luthen og Kolstad, 2018). I tråd med dette siste finner også Sundli (2001) at praksislærere kan være snare med å innta en ekspertrolle og gi råd. Hun omtaler dette som veiledning som kloning, og stiller spørsmål ved om den veiledningen som gis blir mer overføring av praksis enn kritiske og veiledende spørsmål om praksis.

Lignende funn, og kritiske spørsmål i forlengelse av dem, finner vi i internasjonale studier på feltet, hvor fagmiljøene er betydelig større og forskningsperspektivene flere. Crasborn og hans kolleger (2011), som er sentrale forskere innenfor en nederlandsk utdanningskontekst, har identifisert fire veilederroller i praksisveiledning, og konkluderer med at «imperator» rollen er den mest utbredte. Veilederen er aktiv og instruerende, gir konkrete tips og forslag til forbedringer, og har mer fokus på læringsresultat enn læringsprosess (s. 327328). I en større oversiktssiktstudie over internasjonal forskning på feltet, er det nettopp funnet at praksisveilederes tilbakemeldinger til studentene er «narrow», «particularistic» og «technical». Den store majoriteten av tilbakemeldingene handler om de didaktiske spørsmålene hva og hvordan, og mindre hvorfor. Tilbakemeldinger til lærerstudenter som aktualiserer behov for dypere refleksjon over praksis, og som inviterer til utviklende kunnskapsprosesser, forekommer sjelden (Clarke mfl., 2014, s. 175. Se også Timperley, 2001). Dette er resultater og vurderinger, som korresponderer med flere studier om praksisveiledning, hvor det er funnet at veiledningen i hovedsak er knyttet til utførelse av spesifikke handlinger, og inviterer i mindre grad til refleksjon over intensjoner og mål. Dermed tas heller ikke et større spekter av læreres kunnskapsgrunnlag i bruk. Det virker begrensende for muligheten for å anvende teori i diskusjonen, og det virker begrensende for studentenes læringspotensial i samtalene (Helgevold mfl., 2014; Ohnstad og Munthe, 2010; Ottesen, 2006; Sundli, 2001; Solstad, 2013; Søndenå, 2004).

En mulig dimensjon i dette kan være, som Raaen (2017a) har funnet i sin forskning, at praksisveiledere primært forstår seg selv og sin rolle som praktikere, ikke som teoretikere eller kunnskapsutviklere. Rolleforståelse og veiledningspraksis er nært knyttet sammen (Bjuland og Helgevold, 2018; Rachmin og Orland-Barak, 2018). ${ }^{5}$ En åpenbar utfordring er imidlertid at lærerstudenter selv ønsker at praksisveiledere skal opptre som eksperter og fortelle dem hvilke undervisningshandlinger som tjener elevene i spesifikke situasjoner. Studentene etterspør ofte hva praksislærere selv pleier å gjøre

\footnotetext{
${ }^{5}$ Når praksisveileder fra UH-sektoren tar del i praksisveiledningen, kan veiledningen bli beriket ved at ulike perspektiver og kunnskapsformer får plass i veiledningen. Samtidig kan det oppstå utfordringer som gjør den samme praksisveiledningen utfordrende for studentene ved at de ulike veilederne har ulik rolleforståelse, alt etter hva de ser på som sine oppgaver i veiledningsvirksomheten, og at denne nødvendigvis ikke er avklart og kommunisert (Lillejord og Børte, 2014; Zeichner, 2010).
} 
(Ohnstad og Munthe, 2010). I en ny studie av lærerstudenters vurdering av egen praksisveiledning, finner for eksempel Lejonberg (2018) at studentene etterspør «klar veiledning» i sin praksis (s. 313). Med det menes en form for veiledning hvor praksisveiledere gir tydelige tilbakemeldinger og råd om hvordan yrkesutøvelsen bør være. Samtidig rapporterer lærerstudenter at høy veiledningskvalitet blant annet kjennetegnes av at praksislærere oppmuntrer dem til å reflektere før praksislærerne eventuelt kommer med forslag til løsninger (Andreasen og Høigaard, 2017). Her er altså et brudd mellom studentenes egne ønsker for veiledningen når de befinner seg i praksis, og deres refleksjoner over kvaliteter ved den samme veiledningen.

Forskningen viser altså at praksisveiledere har en tilbøyelighet til å veilede studenter gjennom å innta en rådgiverrolle til etterfølgelse, og at studentene selv uttrykker ønsker om at praksisveilederne utøver rollen sin akkurat slik. Det er også funnet at veiledningen er knyttet til utførelse av spesifikke handlinger mer enn å fremme dypere refleksjon og begrunnelser for handling.

\section{Veiledningens egenskaper - tre argument}

Med bakgrunn i forskningsfunnene ovenfor vil jeg nå drøfte praksisveiledningens mulige egenskaper, og med det kaste lys over forutsetninger for at veiledning kan bidra til lærerstudenters profesjonelle utvikling.

\section{Å be om begrunnelser}

Mitt første argument er at praksisveiledning kan bidra til profesjonell utvikling ved at veileder aktivt ber studentene om begrunnelser for handlinger i praksis. Praksis består av både handlinger og teorier om handlinger (Løvlie, 1972; Dale, 1993). Å be om begrunnelser kan forstås som et redskap til å komme i kontakt med studentenes bakenforliggende rasjonale for handlinger. Dette rasjonale blir blant veiledningsteoretikere også omtalt som en form for «praksisteori» (Handal og Lauvås 1999, s. 19), eller "praktisk yrkesteori» (Lauvås og Handal, 2000, s. 180). Men å be om begrunnelser handler om mer enn å identifisere et rasjonale; ${ }^{6}$ det handler også om en bevisst form for kunnskapsanvendelse, noe som videre kan forstås som en forutsetning for utvikling av lærerprofesjonalitet.

Lærerarbeid innebærer anvendelse av kunnskap (jf. Abbott, 1988 i Havnes og Smedby, 2014), men kunnskapsgrunnlaget er komplekst. I profesjonsutøvelsen forvaltes praktisk kunnskap som kommer til uttrykk i handlinger og ferdigheter. I forskningslitteraturen brukes ulike begreper på praktisk kunnskap, eksempelvis Ryles «knowing how» (1949), Erauts «know how» (1994), Shulmans «strategisk

\footnotetext{
${ }^{6}$ Dale (1989) forstår dialoger om profesjonens begrunnelsesnivå som en typisk aktivitet innenfor det tredje kompetansenivået (K3). Et av hans argumenter er at lærere først er profesjonelle når undervisningen blir gjennomført (K1) ut fra didaktisk teori (K3). Sentralt er her aktiviteter som å undersøke, analysere og drøfte intensjoner for undervisningen.
} 
kunnskap» (1986) og fenomener som Doyle identifiserer som «klasseromskunnskap» (1979). Gilje forstår praktisk kunnskap som både praktisk ferdighetskunnskap (å kunne utføre en handling), og som didaktisk ferdighetskunnskap (å kunne lære andre hvordan man utfører den samme handlingen) (Gilje, 2017). Som en konsekvens av dette kan vi forstå læreres praktiske kunnskap som både ferdighet i å selv kunne gjøre det vi ønsker at elevene skal lære, slik som å kunne utføre god svømmeteknikk eller selv å beherske arbeid med leire frem til glaserte keramiske produkter. Samtidig kan lærere utøve god praksis selv om de ikke selv behersker å utføre bestemte handlinger, men ved å kunne formidle hvordan elevene selv skal utføre dem til vellykkede resultat. Lærerens praktiske kunnskap kommer da til uttrykk gjennom didaktisk ferdighetskunnskap.

I profesjonsutøvelsen forvaltes også vitenskapelig kunnskap som kommer til uttrykk ved å vite at noe er (Gilje, 2017; Grimen, 2008a). Slik form for kunnskap er også omtalt som «påstandskunnskap» (Johannesen, 1999), "proposjonell kunnskap» (Shulman, 1986) og som «knowing that» (Ryle, 1949). Det kan for eksempel være tale om kunnskapskilder om mestringsforventning (Bandura, 1977), at språket som kulturelt redskap kan forstås som vesentlig i elevenes læringsprosess (Vygotsky, 1986), eller påstander om at kvaliteten på læreres tilbakemeldinger har implikasjoner for elevenes læring (Hattie og Timperley, 2007).

Grimen hevder at profesjoners kunnskapsbaser i stor grad er heterogene. Det vil si at de er satt sammen av elementer fra forskjellige vitenskapelige disipliner eller kunnskapsfelter (2008a). For lærerprofesjonen viser dette seg ved at kunnskapsgrunnlaget har kilder fra blant annet psykologi, sosiologi, filosofi og historie. Derfor innebærer all profesjonsutøvelse å anvende kunnskaper fra flere vitenskapsfelt. Lærere vil også måtte ta stilling til ulike normative problemstillinger (Gilje, 2017), og stadig foreta verdivalg uten klare regler for prioriteringer (Grimen, 2008a). Selv om det skulle finnes nokså sikker kunnskap på feltet, som profesjonsutøvere har en moralsk plikt til å ta i bruk, kan det være grunner for å modifisere disse pliktene og prioritere annerledes (Bøyum, 2017). Virksomhetenes verdier kan komme i konflikt med hverandre, og det fordrer evne til å utøve skjønn. Lærere må for eksempel forholde seg til lover og læreplaner, men kan komme i situasjoner der verdier i skolens mandat ikke kan prioriteres samtidig. I noen tilfeller kan hensynet til elevens beste komme i konflikt med andre hensyn, som for eksempel vurderingens formål eller hensynet til fellesskapets beste.

Samlet kan vi si at det er ulike former for kunnskap som kombineres i læreres praksis. Læreres profesjonsutøvelse bærer med seg et amalgam av kunnskaper (Grimen, 2008a) eller sammenvevde «nøster av kunnskap, erfaringer og verdier» (Handal og Lauvås, 1999, s. 20). Lærere bør derfor beherske samspillet mellom ulike kunnskapsformer, og videre kunne integrere dem i henhold til de krav praksis til enhver tid stiller. Slike integrative bestrebelser forstår Grimen (2008a) 
som praktiske synteser, hvor «brokker av kunnskap er satt sammen på en bestemt måte fordi de utgjør meningsfulle deler i yrkesutøvelsen forstått som en praktisk helhet eller enhet» (s. 74). Kunnskapsbrokker kan ha kilde i teori fra ulike disipliner, praktisk kunnskap eller fortrolighet med konkrete situasjoner, men det er den praktiske oppgavens karakter som bestemmer hvilke elementer det er relevant å knytte sammen. Hvordan praktiske synteser blir seende ut er imidlertid ikke gitt; god praksis følger ingen oppskrift. Derfor må praktikere gå inn i kunnskapsprosesser for å kunne se sammenhenger mellom generelle kunnskapsressurser om fenomener som inngår i situasjonene og det partikulære ved situasjonene. Mens deler av dette arbeidet har tause dimensjoner ved seg og vises gjennom handling - «we can know more than we can tell» (Polanyi, 1983, s. 4) - kan andre deler verbalt artikuleres og dernest bli del av praksisveiledning. Jeg vil presisere at det verken er hensiktsmessig eller mulig å erstatte all taus kunnskap med verbalt artikulert kunnskap. Samtidig, sett i lys av at det ikke er gitt hvordan praktiske synteser blir seende ut, vil det for utvikling av god praksis være en fordel at hvilke behov for kunnskap som aktualiseres i de spesifikke situasjonene blir tatt opp til diskusjon, og hvordan ulike deler av kunnskap kan settes sammen i henhold til det som er arbeidsoppgavens karakter. $\AA$ be om begrunnelser i praksisveiledning inviterer lærerstudenten inn i slike utviklende kunnskapsprosesser.

Slik kan vi samlet sett si at å be om begrunnelser i praksisveiledning oppøver studentene til å bli oppmerksomme mot, samt øver evnen til å ta i bruk, de kunnskapsressurser som er tilgjengelige og vurderes som relevante for de konkrete situasjonene som det øves i. For konkrete eksempler på veiledningsutsagn i så måte, vil jeg vise til figur 1 . Her skilles det skjematisk mellom utsagn i veiledningen som inviterer til egenvurdering og beskrivelser om undervisningshandlinger, og mellom utsagn om tilbakemeldinger og råd om undervisningshandlinger. Til sist viser figuren eksempler på utsagn som inviterer til begrunnelser for handlinger, og gjennom det også til å gå inn i utviklende kunnskapsprosesser.

\section{Egenskaper Eksempler på veiledningsutsagn}

\begin{tabular}{|l|l|}
\hline \multirow{3}{*}{ Beskrivelser } & $\begin{array}{l}\text { Hva skal du gjøre? } \\
\text { Hvordan vil du gjøre det? } \\
\text { Hva skjedde? }\end{array}$ \\
\cline { 2 - 2 } Egenvurdering & $\begin{array}{l}\text { Hvordan opplevde du at det gikk? } \\
\text { Hva er du fornøyd med? } \\
\text { Hva er du ikke fornøyd med? }\end{array}$ \\
\cline { 2 - 2 } Tilbakemeldinger & $\begin{array}{l}\text { Det som fungerte i denne økten var ... } \\
\text { Det er flott at du ... } \\
\text { Jeg ser at ... }\end{array}$ \\
\cline { 2 - 2 } Å gi råd & $\begin{array}{l}\text { Du kunne kanskje prøvd å ... } \\
\text { Det beste ville være å ... }\end{array}$ \\
\cline { 2 - 2 }
\end{tabular}


Det du bør jobbe med til neste gang er ...

Hvorfor vil du gjøre det på den måten?

\begin{tabular}{l|l} 
Begrunnelser & Hva kan være grunner til at det ble/blir slik?
\end{tabular}

Hva er grunnlaget for å forstå det sånn?

Figur 1 Egenskaper ved veiledning om pedagogiske handlinger i praksis ${ }^{7}$

Det finnes flere varianter av praksisveiledning enn det figuren viser; den er ikke uttømmende i så måte. Dessuten vil utsagn i praksisveiledning som oftest ikke opptre som gjensidig ekskluderende egenskaper. Et utsagn om råd kan for eksempel ta opp i seg begrunnelser for hvorfor rådet blir gitt, det samme kan utsagn om tilbakemeldinger. Like fullt kan figuren tjene som et analytisk redskap for å identifisere hva vi kan forstå med at praksisveileder inviterer til kunnskapsprosesser ved å be om begrunnelser for handling.

Et relevant spørsmål i forlengelse av figur 1 er hvilke behov for kunnskap som faktisk aktualiseres i de spesifikke situasjonene som studentene møter. Noen ganger gis moralske prinsipper plass, andre ganger didaktisk teori eller ferdigheter. Hovedsaken er at brokker av kunnskap henger sammen fordi de er nødvendige for å kunne gjennomføre bestemte arbeidsoppgaver (Grimen, 2008), men det er opp til studenten selv, med utgangspunkt i oppgavene som skal gjennomføres, hvordan sammenhengen av kunnskapsbrokker til enhver tid blir seende ut. Derfor må overveielser og kritiske vurderinger om hvilke kunnskapselementer som er hensiktsmessige å knytte sammen bli del av praksisveiledningen. Slike kunnskapsprosesser stimulerer til bevissthet om bakenforliggende rasjonale for handlinger og gir dessuten også grunnlag for å kunne identifisere hva studentene trenger å vite mer om for å kunne foreta bedre handlingsvalg. For profesjonell utvikling handler også om å identifisere behovet for å hente inn ny kunnskap i samhandling med den informasjon som allerede foreligger (Havnes og Smedby, 2014). Dersom slike kunnskapsprosesser skal bli del av praksisveiledning er det arbeidsoppgavenes karakter som må bestemme hva det er relevant å veilede om, og ikke behov som styres av andre aktører i utdanningen (jf. Raaen, 2017b). Det er arbeidet i seg selv som må være sentreringspunkt for studentenes profesjonelle utvikling. Noe som også er i tråd med det situerte perspektivet; at kunnskapen er knyttet til spesifikke kontekster (Lave og Wenger, 1991).

\section{Å gi motstand på begrunnelser}

Mitt andre argument er at det eksisterer et særlig potensial for studentenes profesjonelle utvikling knyttet til det å ta begrunnelser opp til diskusjon og å

\footnotetext{
${ }^{7}$ Utsagnene er inspirert av empiriske studier på veiledning: Bjerkholt, 2017; Bjuland og Helgevold, 2018; Clarke mfl., 2014; Crasborn mfl., 2011; Helgevold mfl., 2014; 2016; Jensen, 2016; Ohnstad og Munthe, 2010; Ottesen, 2006; Sundli, 2001; Solstad, 2013; Ulvik mfl., 2017.
} 
utfordre studentene som en del av veiledningen. Er studentenes begrunnelser for handling gyldige? Finnes det bedre argumenter? Kan vi se aktuelle saksforhold på andre måter?

Løvlie (1994) hevder, når han i et av sine arbeider argumenterer for en teoretisk rekonstruksjon av dialogpedagogikken, at alle standpunkt bør kunne gjøres til gjenstand for diskusjon og avgjøres med det bedre argument. Enhver ytring, påstand eller handling bør prøves i en diskusjon, der samtalepartnerne hele tiden må forutsette muligheten av det bedre argument. Hvis en ikke våger seg inn i dette rommet $\mathrm{i}$ praksisveiledning, kan samtalene begrenses til «den gode samtale» (s. 21), hvor formålet med samtalen er at det skal råde konsensus, og hvor harmoni mellom praksislærer og student blir premissleverandør for veiledningens innhold. I slike veiledningssamtaler vil også interne målestokker om hva som er rammer for god praksis råde, uten selvkritikk og uten kritikk utenfra (jf. Løvlie, 1994). I dette perspektivet kan kunnskapsprosessene bli nærsynte og begrenset av den lokale konteksten (Ertsås og Irgens, 2017).

Hvorfor er kravet om gode argumenter viktig? - spør Løvlie: «Jo, det henger sammen med at den gode samtale tenderer mot å godta ethvert argument som et godt argument» (Løvlie, 1994, s. 24). Dersom samtalene skrider frem på slike premisser, er det nærliggende å bli autoritær i den forstand at man forteller hva studentene skal kunne og hvordan de skal tenke. Istedenfor å følge veien inn i et slikt blindspor, kan gyldige handlinger best sikres ved å gi det bedre argument forrangen. Derfor gjelder det å be om argumenter og ta dem opp til diskusjon. For det bedre argument kommer ikke fram uten at deltakerne bryner sine kunnskaper og ferdigheter mot andres, i en kappestrid om det bedre argument. Å gi motstand på begrunnelser er i dette perspektiv forenlig med arven etter Bakhtin. Gjennom dialogismens linser kan vi forstå at utvikling skjer gjennom samspill mellom personer som representerer ulike erfaringer og kunnskaper. Ikke bare ved at det er sameksistens av ulike kompetanser eller av ulike stemmer, men ved at stemmene stilles opp mot hverandre, motsier hverandre eller gjensidig utfyller hverandre. Det er ikke automatisk gitt at de ulike stemmene står i dialog med hverandre, men dersom ulike erfaringer, kunnskaper, perspektiver eller synspunkter brytes mot hverandre, kan studentenes kunnskaper endre seg (Dysthe, 1995).

Spørsmålet blir hvordan dette kan kombineres med det relasjonelle aspektet i samtalen, som vi fra den empiriske forskningen også vet at er av betydning for studentenes læring i praksis (Clarke mfl., 2014; Hudson, 2016). Er det mulig å skape et samtaleklima hvor det å bryne seg på det bedre argument ikke blir til studentens selvforsvar? Eller for å spørre på en annen måte: må vi nødvendigvis velge mellom harmoni i relasjonsaspektet og disputter om saksforholdet? Jeg vil argumentere for at en praksisveiledning hvor det gis motstand på studentenes begrunnelser for handling, ikke trenger å bli til konfrontasjon i negativ forstand. For det første kan metakommunikasjon om hensikten med samtalen være et kommunikativt hjelpemiddel til å ivareta tilliten mellom praksisveileder og 
student. For det andre kan det å gi motstand på begrunnelser prinsipielt bli anerkjent som en menneskevennlig handling, ganske enkelt fordi det handler om å ta den andre på alvor som subjekt i egen lærerutvikling. Skjervheim (1996) skriver at «dersom vi objektiverer den andre, er det ikkje så lett på same tid å ta han og det han seier alvorleg» (s. 74. Kursiv i original). Videre skriver han «å ta den andre alvorleg er det same som å vera viljug til å ta hans meiningar opp til ettertanke, eventuelt diskusjon» (s. 74-75). Dette handler om å anerkjenne den andre til å bruke sin egen fornuft, ta selvstendige initiativ og til å ta ansvar. Og ikke det motsatte; å se på den andre som et middel for påvirkning, tilpasning og i ytterste konsekvens bidra til at studentene blir til kloning av praksislærer (jf. Sundli, 2001).

Å gi motstand på begrunnelser er viktig for å kvalifisere studentene til å kunne svare for seg i de vurderinger de gjør. Å være profesjonsutøver er å utføre tjenester basert på spesialisert kunnskap, kunnskap som ikke er allment tilgjengelig. Den forvaltes av profesjonene og det gir profesjonene en rolle som formidlere og fortolkere. Profesjonsutøveren tar den spesialiserte kunnskapen i bruk for å løse praktiske problem, og dermed samtidig et ansvar for å forvalte klientenes saker på en best mulig måte. Den andre part trenger profesjonsutøverens kompetanse og stoler på at denne kompetansen er til stede når de overlater sakene sine til den profesjonelle. Konsekvensene av dette blir å anse profesjonsutøvelse som et tillitsbasert ansvar (Molander og Terum, 2008). Hva som er godt lærerarbeid er dessuten influert av skjønnsmessige vurderinger og det stilles derfor krav til den som får myndighet (Grimen, 2008b). Profesjonene har derfor plikt til å svare for hva de gjør, og må kunne gi gode grunner for sine handlinger (Molander og Terum, 2008). Legitimering av profesjonshandlinger ligger i argumenters overbevisende kraft. Molander og Terum skriver:

Kravet om rasjonell begrunnelse er den kulturelle modernitetens grunnleggende prinsipp og den mest allmenne normative fordringen til profesjonell virksomhet. Når mindre tas for gitt, og når stadig mer blir åpent for prøving, er argumenters overbevisende kraft det eneste som står igjen som legitimeringsgrunn. (2008, s. 15)

I så måte blir studentens krav om å gi gode argumenter i praksisveiledning et kvalifiserende bidrag for å kunne delta i å utvikle en lærerprofesjon som er i stand til å svare for den tilliten de er tildelt samfunnet. Og i så måte kan vi si at det eksisterer et særlig potensial for profesjonell utvikling knyttet til det å ta begrunnelser opp til diskusjon.

\section{Å samarbeide om praksis}

Til sist vil jeg argumentere for at praksisveiledning kan bidra til studentenes profesjonelle utvikling ved at praksisveileder og student samarbeider om saksforholdet, og at ikke han eller hun begrenser sitt handlingsrom til å stille spørsmål til studenten om saksforholdet. 
En veilederrolle hvor praksislærer begrenser seg til å stille spørsmål til studentene, kan knyttes til Handal og Lauvås (1999) sine klassiske veiledningsideer om refleksjon over handling. Sentralt er her at læreres praktiske yrkesteori er styrende for praksis, og at læreres teori om praksis har subjektive elementer i seg. Slik ses veisøker som ekspert på sin egen praksisteori, veiledningen skal følgelig foregå på veisøkers vilkår, og veilederen skal primært være en samtalepartner som gjennom sine spørsmål hjelper veisøker til å reflektere. Handal og Lauvås er kritisert for at dette i praksis innebærer en indirekte veilederrolle, hvor veilederen gjennom sin andreorientering og spørsmål legger til rette for den andres refleksjon (Bjerkholt, 2017; Lejonberg, 2016). Veilederrollen begrenses slik til å være en samtalepartner (Skagen og Smith, 2018). Worum (2014) setter dette i relasjon til et individorientert kunnskapssyn på veiledning: «En veiledningsform som bare etterspør det enkelte individs svar på utformede spørsmål [...] bærer i seg et individorientert kunnskapssyn. Utvikling av mening og forståelse tenkes primært å foregå i det enkelte individet» (s. 32).

Praksis er imidlertid, slik jeg ser det, ikke et individuelt anliggende. Det er ikke opp til den enkelte lærer og hans eller hennes kunnskapsgrunnlag å rettferdiggjøre sine handlinger. Jeg mener det er gode grunner for å tenke at individets intensjoner, rasjonale og praksisteori bør suppleres, utfordres og stå i dialog med profesjonsfellesskapets kriterier og krav for hva som er god profesjonsutøvelse. Profesjonsutøving innebærer betydelig autonomi, basert på tillit, men det er ikke opp til den enkelte å være fortolker av hva som er god praksis. Det organisatoriske aspektet ved profesjoner innebærer at de må opptre som en organisert gruppe, en sammenslutning som har utviklet en kollektiv selvforståelse som profesjon. Profesjonsmedlemmene må opptre i samsvar med standarder for god yrkesutøvelse (Molander og Terum, 2008). I dette perspektiv er det viktig at studentene i sin utdanning møter profesjonsfellesskapets kriterier, representert gjennom praksisveileder, for hva som kjennetegner god praksis.

At praksisveileder begrenses til å være spørsmålsstiller er også problematisk fordi han eller hun dermed blir avskåret fra å bidra med merkunnskap i samtalen, og til å ta rollen som en «knowledgeable other» i samtalen (Bjuland og Helgevold, 2018). Særlig innen en utdanningskontekst kan dette få uheldige konsekvenser, fordi det som oftest vil være, eller skal være, asymmetri i kunnskaper mellom den som gir utdanning og den som mottar utdanning (Skagen, 2013). I utdanningen kan det også være behov for å dekomponere praksis for å kunne gi studentene innsikt i mindre deler av et større hele, som i neste omgang kan gi grunnlag for å mestre stadig mer krevende praksiser (Grossman mfl., 2009). For å vite hva man trenger innsikt $\mathrm{i}$, er det en forutsetning å ha inngående kjennskap til autentiske praksiser, slik praksisveiledere ofte har. Dessuten er autentiske praksiser komplekse, og denne kompleksiteten kan være vanskelig å analysere. En av de viktigste begrensningene blant noviser er å tolke klasseromssituasjoner (Berliner, 1986; 1994), og eksperten kan bidra med sin merkunnskap i dette arbeidet 
(Nilssen, 2007). Det er derfor legitimt at veileder bidrar med merkunnskap i praksisveiledning.

Ohnstad og Munthe (2010) finner i en studie om praksisopplæring i norsk grunnopplæring at studentene raskt blir satt inn som lærere med ansvar for å planlegge og å gjennomføre hele undervisningsøkter. Drøfting av praksislærers undervisning er mindre vanlig. Dermed kan det være vanskelig for studentene å få tak i de erfarne lærernes kunnskapsbase og deres begrunnelser for handlingsvalg. Ohnstad og Munthe viser til Brandsford og Darling-Hammond (2005), som finner at en av faktorene som har betydning for studentenes læringsmuligheter i praksisopplæringen, er at de blir veiledet av lærere som gjør egen tenkning om undervisningen eksplisitt, også i planleggingsfasen (Ohnstad og Munthe, 2010).

Samlet sett kan medskapende samspill mellom praksisveileder og student forstås som en forutsetning for å kunne innvie studentene i de kunnskapsprosesser som ligger til grunn for yrkesutøvelsen. I henhold til Nerland og Hermansen (2017) sin argumentasjon kommer ikke meningsskaping knyttet til kunnskap i profesjonelt arbeid fra individet alene, men oppstår i omgangen med kunnskapsressurser og innenfor rammen av kollektive aktiviteter, slik som praksisveiledning er (se også Bjuland og Helgevold, 2018). Derfor vil det nettopp være av betydning at studentene får rik tilgang til måten kunnskap utforskes, deles og vurderes på i profesjonens kunnskapskultur. Ikke bare bør de prosedurale aspektene ved arbeidet - kunnskap om hvordan man går frem - bli transparente for studentene. De trenger også støtte i bruk av det mangfold av kunnskapsressurser som tilhører profesjonens praksisformer. Det kan være teorier, prinsipper, modeller og verktøy representert for eksempel gjennom undervisningsmateriell eller læreplan. På bakgrunn av dette kan vi forstå at studentenes profesjonelle utvikling er tett forbundet med at praksisveileder retter oppmerksomhet mot kunnskapsressurser som er tilgjengelige, samt bidrar med sin merkunnskap i måten de brukes på ut fra arbeidets karakter.

Ved å argumentere for at veileders merkunnskap bør ha plass i praksisveiledning, er det kanskje nærliggende å slutte at han eller hun bør opptre som rådgiver i møte med studenter under utdanning. Vi har ovenfor sett at empirisk forskning viser at praksisveiledere er tilbøyelige til å formilde råd (Sundli, 2001; Crasborn mfl., 2011; Lejonberg, 2018). En fallgruve vil her være om praksislærer opptrer som om de vet best (Ulvik mfl., 2017) og formidler råd som studenter oppfatter at er krav som skal som følges. Å motta råd kan virke forpliktende. I ytterste konsekvens kan forventninger om at rådene skal følges, bevisst eller ubevisst, gjøre studenten til objekt for definerte læringsresultater; «jeg må få henne til å forstå ...» og «det beste er om du velger ...». Et slikt samspill i praksisveiledning vil kunne sette grenser for å møte hverandre som et «du» (Buber, 1992) kjennetegnet av tillit, aksept og bekreftelse. $\AA$ samhandle med studentene som et «du» vil kreve at man er taktfull. Van Manen (1993) skriver at «pedagogisk takt kommer primært til uttrykk som en lydhør og oppmerksom 
orientering i samværet og samhandlingen med barn» (s. 135). Det dreier seg om den holdning en inntar i møte med den andre; om å være åpen for den andres opplevelse av situasjonen.

Her kan Brunstads metafor om mentoren som nomade bidra med innsikter (2018). Brunstad skriver at det i veiledning kan være forskjell i alder, erfaring, kunnskap, makt, trygghet og mestring av arbeidssituasjon. I dette bildet har veilederen vært på stedet lenge, mens veisøkeren er nykommer. Veisøker vil i dette møtet være ekstra sårbar, men ved å tenke på veilederen som nomade, snur en perspektivet. Ved at veilederen blir den fremmende, som nykommer i veisøkers liv, mener Brunstad at det kan etableres bedre vilkår for utvikling. Som nomade vil en bare for en kort stund oppholde seg i den andres nærhet. Derfor må det fremmede stedet, og den andres liv og eiendom, behandles på en respektfull måte. Til det fremmede og midlertidige stedet tar veileder med seg det han eller hun trenger av kompetanse, ikke mer. Den nomadiske flyktigheten representerer noe av veileders styrke; for noen ganger ser nomaden mer enn den fastboende. Faren er imidlertid at veileders mererfaring og merkunnskap blir det som stenger for den andres utvikling. Gode erfaringer blir så påtrengende at det til slutt ikke er rom for refleksjon og undring. Veileders styrke kan bli problemet. Nomadens utfordring blir derfor å sette sitt eget på vent. Selvbesinnelse er derfor en dyd (Brunstad, 2018). Å se på praksisveileder som nomade kan gi redskap til å finne balansepunkter mellom at praksislærer kan ta med seg sin merkunnskap og mererfaring til studentenes sted, men samtidig i respekt for hvor studentene er i deres utvikling. $\AA$ forstå praksisveileder som nomade kan være et fruktbart manøvreringspunkt i hvordan praksislæreres mererfaring og merkunnskap kan inngå i samarbeidet om studentenes prosess for profesjonell utvikling.

Mot denne bakgrunn er det legitimt at praksisveileder kan bidra med sin merkunnskap med sikte på å gi studenten den dypere innsikt han eller hun trenger for å selv adekvat kunne vurdere en situasjon eller ta en riktig beslutning. I Bollnows (1969) forståelse av rådgivning er nettopp dette poenget. Han forklarer oss at i rådgivning konfronteres man med en rekke muligheter som blir avveid mot hverandre. Når man så anbefaler en av mulighetene, utdypes og begrunnes dette med saklige argumenter. Dette fordi rådgiverens oppgave er å hjelpe den som søker råd til å få innsikt i forutsetningene for sin egen avgjørelse. Rådgivning impliserer derfor alltid en mer eller mindre utførlig begrunnelse for det rådet som blir gitt. Det er ikke rådgiverens oppgave å ta selve avgjørelsen. Rådgiverens ansvar er avgrenset til å gi saklige opplysninger om saksforholdet og på den måten gi den andre bedre innsikt i forutsetningene for sin egen avgjørelse. Praksisveileders merkunnskap i form av råd må derfor alltid ledsages av utførlige begrunnelser for hva som ligger til grunn for bruk av merkunnskapen gitt de situasjonene studenten står overfor. Slik kan praksisveileders merkunnskap inngå i medskapende samspill knyttet til kunnskap i lærerarbeid og med det innvie studentene i de kunnskapsprosesser som ligger til grunn for yrkesutøvelsen. Sagt 
på en annen måte; slik kan praksisveiledning bidra til studentenes profesjonelle utvikling.

\section{Konklusjon}

Profesjonsutviklende veiledningssamtaler for lærerstudenter i praksis er en reell mulighet, forutsatt at samtalene innehar bestemte kvaliteter. Tidligere empirisk forskning viser at praksisveiledning er knyttet til utførelse av spesifikke handlinger og at praksisveiledere mer gir råd og fremstår som eksperter på spesifikke undervisningssituasjoner enn å fremme kritisk refleksjon og etterspørre begrunnelser for handling. Supplert med veilednings- og profesjonsteori har jeg i denne artikkelen teoretisk argumentert for at profesjonell utvikling gjennom praksisveiledning forutsetter at veileder ber studenter om begrunnelser, gir motstand på begrunnelser, samt inngår $\mathrm{i}$ et reelt samarbeid om aktuelle saksforhold i praksis. Artikkelens tre argumenter står i nær sammenheng med hverandre. Praksisveiledning er et dynamisk samspill mellom student og lærer, basert på gjensidig respekt og tillit, om å utvikle god praksis. I dette samspillet vil naturligvis både handlingsbegrunnelser, kritikk og samarbeid foregå om en annen.

Samlet sett kan de tre fenomenene begrunnelse, motstand og samarbeid som en forutsetning for profesjonell utvikling sees i lys av at lærerarbeid er å anvende kunnskap på spesifikke problem. Hva praktikere velger å gjøre i undervisningssituasjoner kan ikke avledes fra gitte handlingsregler, eller bare læres ved at studenter søker å etterligne sine praksislærere, slik empirisk forskning viser at kjennetegner veiledningspraksisen. Det må stadig utøves skjønn basert på særegne forhold i pedagogiske situasjoner. Lærerarbeid er slik å forstå som fortolkning av enkelttilfeller i lys av generell kunnskap. Det følger logisk at det i dette fortolkningsarbeidet er viktig å kunne begrunne handlingsvalg, både fordi kvalifisert fortolkning ikke kan løsrives fra profesjonens kunnskapsgrunnlag, og fordi begrunnet handling på et adekvat kunnskapsgrunnlag bidrar til en legitim profesjonsutøvelse gitt den tillit samfunnet har gitt lærerprofesjonen til å ivareta komplekse undervisningsoppgaver. Og nettopp for å sikre at legitimiteten ikke skal stivne i tankemønstre, eller vanetenkning, avstøpt i interne målestokker for hva som kan sies å kjennetegne god praksis, fordres det kritiske perspektivet i praksisveiledning. Kunnskapsutviklende veiledning er stadig på jakt etter gode argumenter og tillater at ulike stemmer får brynes mot hverandre.

For lærerstudenter er det altså gjennom den veiledede praksis at forbindelser, eller integrasjon, av et fragmentert kunnskapsgrunnlag kan realiseres og komme til uttrykk, og det er gjennom samarbeid og deltakelse i tilhørende kunnskapsprosesser at profesjonell utvikling potensielt sett kan skje. Det hele hviler på en forståelse av kunnskap som situert, konstruert og distribuert i sosial praksis. Det følger av drøftingen i denne artikkelen at veilederrollen er kompleks og krevende. Praksislæreres egen veiledningspraksis er av betydning for hvorvidt 
lærerstudenter får rom til å forene den forskningsbaserte kunnskapen de har tilegnet seg i utdanningsløpet med den partikulære og erfaringsbaserte kunnskapen som oppstår i møte med praksis. Skal lærerutdanningene kunne legge til rette for profesjonsutviklende kunnskapsprosesser, fordrer det derfor et nært samarbeid mellom utdanningsinstitusjoner og praksisfeltet, hvor egenskaper ved veiledningssamtalene drøftes, og hvor siktemålet fremstår klart for alle parter: å aktivt gripe de potensielle muligheter for profesjonell utvikling samtalevirksomheten i studentenes praksisperioder bærer med seg.

\section{Om forfatteren}

Edel Karin Kvam er førsteamanuensis i pedagogikk ved Universitetet i Bergen. Hennes forskningsinteresser omfatter profesjonell utvikling, lærersamarbeid, veiledning i utdanning og i overgang til yrket.

Institusjonstilknytning: Institutt for pedagogikk, Universitetet i Bergen, Postboks 7807, 5020 Bergen

E-mail: edel.kvam@uib.no

\section{Referanser}

Andreasen, J. K. og Høigård, R. (2017). Praksisopplæringen i grunnskolelærerutdanningene en studie om veiledningskvalitet. Uniped, 40 (3), 222-234.

Bandura, A. (1977). Self-efficacy: Toward a unifying theory of behavioral change. Psychological Review, 84, 191-215.

Berliner, D. C. (1986). In pursuit of Expert Pedagogue. Educational Researcher, 15 (7), 5-13.

Berliner, D. C. (1994). Expertise: The wonders of exemplary performance. I: J. N. Mangieri og C. Collins Block (red.), Creating powerful thinking in teachers and students (s. 141-186). Ft. Worth, TX: Holt, Rinehart and Winston.

Bjerkholt, E. (2017). Profesjonsveiledning. Fra praktisk virksomhet til teoretisk felt. Oslo: Cappelen Damm Akademisk.

Bjuland, R. og Helgevold, N. (2018). Dialogic processes that enable student teachers' learning about pupil learning in mentoring conversations in Lesson Study field practice. Teaching and Teacher Education, 70, 24-254.

Bollnow, O. F. (1969). Eksistensfilosofi og Pedagogikk. København/Oslo: Christian Eijlers` Forlag.

Brunstad, P. O. (2018). Mentoren som nomade. Ansatser til en veiledningsetikk. I: K. Smith og M. Ulvik (red.), Veiledning av nye læerere. Nasjonale og internasjonale perspektiver (2. utg.). (s. 205-215). Oslo: Universitetsforlaget.

Buber, M. (1992). Jeg og du. Oslo: Cappelen Forlag.

Bøyum, S. (2017). Profesjonell kunnskapsetikk og intellektuelle dygder i profesjonsutdanning. I: S. Mausethagen og J.-C. Smedby (red.), Kvalifisering til profesjonell yrkesutøvelse (s. 34-43). Oslo: Universitetsforlaget. 
Clarke, A., Triggs, V. og Nielsen, W. (2014). Cooperating Teacher Participation in Teacher Education: A Review of the Literature. Review of Educational Research, 85 (2), 163202.

Crasborn, F., Hennissen, P., Brouwer, N., Korthagen, F. og Bergen, T. (2011). Exploring a two-dimensional model of mentor teacher roles in mentoring dialogues. Teaching and Teacher Education, 27, 320-331.

Dahl, T., Askling, B., Heggen, K., Kulbrandstad, L. I., Lauvdal, T., Qvortrup, L., Salvanes, K. G., Skagen, K., Skrøvset, S., Thue, F. W. og Mausethagen, S. (2016). Om lcererrollen. Et kunnskapsgrunnlag. Oslo: Fagbokforlaget.

Dale, E. L. (1989). Pedagogisk profesjonalitet. Om pedagogikkens identitet og anvendelse. Oslo: Gyldendal Norsk Forlag.

Dale, E. L. (1993). Den profesjonelle skole. Med pedagogikken som grunnlag. Oslo: Ad notam Gyldendal.

Doyle, W. (1979). Making managerial decisions in classrooms. I: D. L. Duke (red.), Classroom Management. The Seventy-eighth Yearbook of the National Society for the Study of Education (s. 42-74). Chicago: University of Chiacgo Press.

Dysthe, O. (1995). Det flerstemmige klasserommet. Skriving og samtale for å læere. Oslo: Ad Notam Gyldendal.

Eide, M. L., Brekke, M. B. R. og Holthe, A. (2017). Teoriens manglende plass i praksissamtalen. Acta Didactica Norge, 11(1), 1-16.

Eraut, M. (1994). Developing Professional Knowledge and Competence. London: The Falmer Press.

Ertsås, T. I. og Irgens, E. J. (2017). Professional theorizing. Teachers and Teaching. Theory and Practice, 23(3), 332-351.

Gilje, N. (2017). Profesjonskunnskapens elementære former. I: S. Mausethagen og J-C. Smedby (red.), Kvalifisering til profesjonell yrkesutøvelse. Oslo: Universitetsforlaget. (s. 21-33). Oslo: Universitetsforlaget.

Grimen, H. (2008a). Profesjon og kunnskap. I: A. Molander og L. I. Terum (red.), Profesjonsstudier (s. 71-86). Oslo: Universitetsforlaget.

Grimen, H. (2008b). Profesjon og tillitt. I: A. Molander og L. I. Terum (red.), Profesjonsstudier (s. 197-215). Oslo: Universitetsforlaget.

Grossman, P., Hammerness, K., McDonald, M. (2009) Redefining teaching, re-imagining teacher education. Teachers and Teaching, theory and practice, 15 (2), 273-289.

Handal, G. og Lauvås, P. (1999). På egne vilkår. En strategi for veiledning med lærere (2. utg.). Oslo: Cappelen akademisk forlag.

Hattie, J. og Timperley, H. (2007). The power of feedback. Review of Educational Research, 77 (1), 81-112.

Havnes, A. og Smedby, J-C. (2014). Professional development and the profession. I: S. Billett, C. Harteis og H. Gruber (red.), International Handbook of Research in Professional and Practice-based Learning (s. 915-954). Dortrecht: Springer

Helgevold, N., Næsheim-Bjørkvik, G. og Østrem, S. (2014). Veiledningssamtaler i lærerstudentenes praksisperioder - innhold og prosesser. I: A. B. Reinertsen, B. Groven, A. Knutas og A. Holm (red.), FoU i praksis 2013 conference proceedings (s. 133-141). Trondheim: Akademika forlag.

Hudson, P. (2016). Forming the Mentor-Mentee Relationship. Mentoring \& Tutoring: Partnership in Learning, 24 (1), 30-43.

Jensen, A. R. (2016). Veiledningsritualet. En dialektisk studie av formaliserte veiledningssamtaler i lcererutdanningens praksisperiode. Avhandling for graden philosophiae doctor (Ph.d.). Fakultet for humaniora og pedagogikk. Institutt for pedagogikk. Universitetet i Agder. 
Johannesen, K. S. (1999). Praxis och tyst kunnande. Stockholm: Dialoger.

Kunnskapsdepartementet (2013). Forskrift om rammeplan for lektorutdanning for trinn 8-13. Hentet 4. desember 2018 fra https://lovdata.no/dokument/SF/forskrift/2013-03-18288?q=forskrift\%20om\%20rammeplan\%20for\%20lektorutdanning

Kunnskapsdepartementet (2015). Forskrift om rammeplan for praktisk-pedagogisk utdanning. Hentet 4. desember 2018 fra https://lovdata.no/dokument/SF/forskrift/2015-12-21$\underline{1771}$

Kunnskapsdepartementet (2016a). Forskrift om rammeplan for grunnskolelcrerutdanning for trinn 1-7. Hentet 4. desember 2018 fra https://lovdata.no/dokument/SF/forskrift/2016$\underline{06-07-860}$

Kunnskapsdepartementet (2016b). Forskrift om rammeplan for grunnskolelcererutdanning for trinn 5-10. Hentet 4. desember 2018 fra https://lovdata.no/dokument/SF/forskrift/2016-06-07-861

Kunnskapsdepartementet. (2017). Overordnet del - verdier og prinsipper. Oslo: Kunnskapsdepartementet.

Lauvås, P. og Handal, G. (2000). Veiledning og praktisk yrkesteori. Oslo: Cappelen Akademisk Forlag.

Lave, J., og Wenger, E. (1991). Situated learning. Legitimate Peripheral Participation. Cambridge: Cambridge University Press.

Lejonberg, E. (2016). Hva kan bidra til god veiledning? En problematisering basert på veilederes og veisøkeres perspektiver på veiledning av begynnende lcerere. Avhandling for graden philosophiae doctor (Ph.d.). Institutt for lærerutdanning og skoleforskning. Utdanningsvitenskapelig fakultet. Universitetet i Oslo.

Lejonberg, E. (2018). Lektorstudenter i praksis: mestringsforventninger og vurderinger av veiledning. Uniped, 31 (3), 30-318.

Lillejord, S. og Børte, K. (2014). Partnerskap i læererutdanningen - en forskningskartlegging - KSU 3/2014. Oslo: Kunnskapssenter for utdanning.

Luthen, G. og Kolstad, O. (2018). Veiledning i lærerstudenters praksisopplæring - et bidrag til læring og utvikling? Nordvei, 3(1), 30-43.

Løvlie, L. (1972). Universitetspedagogikk - eller debatten som ble vekk. I: N. Mediaas, J. Houge-Thiis, S. Haga, J. Ellingjord og B. Bjørklid (red.), Etablert pedagogikk - makt eller avmakt? (s. 29-35). Oslo: Gyldendal.

Løvlie, L. (1994). Det pedagogiske argument. Oslo: Cappelens Forlag.

Mausethagen, S. (2015). Læreren i endring? Om nye forventninger til lcererprofesjonen og læererarbeidet. Oslo: Universitetsforlaget.

Molander, A. og Terum, L. I. (2008). Profesjonsstudier - en introduksjon. I: A. Molander og L. I. Terum (red.), Profesjonsstudier (s. 13-27). Oslo: Universitetsforlaget.

Nerland, M. og Hermansen, H. (2017). Sosiomaterielle perspektiver på profesjonskvalifisering: kunnskapsressursenes betydning. I: S. Mausethagen og J-C. Smedby (red.), Kvalifisering til profesjonell yrkesutøvelse (s. 167-179). Oslo: Universitetsforlaget.

Nielsen, K. og Kvale, S. (1999). Mesterlære. Lœring som sosial praksis. Oslo: Ad Notam Gyldendal.

Nilssen, V. L. (2007). Seeing the kids - seeing the student teachers; dealing with two arenas the whole way. A case study of a coorperating teachers mentoring first-year student teachers 'mathematics teaching. (Doktorgradavhandling. Faculty of social sciences and technology management. Department of education). Trondheim: NTNU

Ohnstad, F. O. og Munthe, E. (2010). Veiledet praksisopplæring og lærerstudenters kvalifisering. I: P. Haug (red.), Kvalifisering til læeraryrket (s. 140-164). Oslo: Abstrakt forlag. 
Orland-Barak, L. (2014). Mediation in mentoring: A synthesis of studies in Teaching and Teacher Education. Teaching and Teacher Education, 44, 180-188.

Ottesen, E. (2006). Talk in practice. Analysing student teachers' and mentors' discourse in internship. Oslo: Universitetet i Oslo.

Polanyi, M. (1983). The Tacit Dimension. Glouchester, Mass: Peter Smith.

Rachamim, M. og Orland-Barak, L. (2018). When style meets pattern in mentoring talk: implications for student teacher community learning environments in practice teaching. Cambridge Journal of Education, 48 (5), 657-675.

Ryle, G. (1949). The Concept of Mind. London: Hutchinson.

Rønnestad, M. H. (2008). Profesjonell utvikling. I: A. Molander og L. I. Terum (red.), Profesjonsstudier (s. 279-294). Oslo: Universitetsforlaget.

Raaen, F. D. (2017a). Placement mentors making sense of research-based knowledge. Teacher development, 21 (5), 635-654.

Raaen, F. D. (2017b). Organisering og utbytte av praksisopplæringen. I: S. Mausethagen og JC. Smedby (red.), Kvalifisering til profesjonell yrkesutøvelse (s. 106-117). Oslo: Universitetsforlaget.

Shulman, L. S. (1986). Those who understand: knowledge growth in teaching. Educational Researcher, 15(2), 4-14.

Skagen, K. (2013). I veiledningens landskap. Innføring i veiledning og rådgivning (2. utg.). Oslo: Cappelen Damm Akademisk.

Skagen, K. og Smith, K. (2018). Mentoren som veileder og vurderer. I: K. Smith og M. Ulvik (red.), Veiledning av nye lerere. Nasjonale og internasjonale perspektiver (2. utg.). (s. 111-123). Oslo: Universitetsforlaget.

Skjervheim, H. (1996). Deltakar og tilskodar og andre essays. Oslo: Aschehoug.

Smedby, J-C. og Mausethagen, S. (2017). Profesjonskvalifisering. I: S. Mausethagen og J-C. Smedby (red.), Kvalifisering til profesjonell yrkesutøvelse (s. 11-20). Oslo: Universitetsforlaget.

Solstad, A. G. (2013). Profesjonsorientert refleksjon i praksisopplæringen - en utfordring for lærerutdanningen. Norsk Pedagogisk Tidsskrift, 97 (2), 97-109.

Sundli, L. (2001). Veiledning i lererutdanningens praksis - mellom refleksjon og kontroll. (Avhandling til ph.d.-graden ved Danmarks Pædagogiske Universitet. Revidert utgave. HiO-rapport, nr. 15). Oslo: Høgskolen i Oslo.

Søndenå, K. (2004). Kraftfull refleksjon i lærarutdanninga. Oslo: Abstrakt Forlag.

Tillema, H. H., Smith, K. og Leshem, S. (2011). Dual roles - conflicting purposes: a comparative study on perceptions on assessment in mentoring relations during practicum. European Journal of Teacher Education, 34 (2), 139-159.

Timperley, H. (2001). Mentoring Conversations Designed to Promote Student Teacher Learning. Asia-Pacific Journal of Teacher Education, 29 (2), 111-123.

Ulvik, M., Helleve, I. og Smith, K. (2017). What and how student teachers learn during their practicum as a foundation for further professional development. Professional Development in Education, 44 (5), 638-649.

van Manen, M. (1993). Pedagogisk takt. Betydningen av pedagogisk omtenksomhet. Nordås: Caspar Forlag.

Vygotsky, L.S. (1986). Thought and language. Cambridge, Mass: MIT-Press.

Worum, K. S. (2014). Veiledning, kunnskapssyn og danning. Norsk Pedagogisk Tidsskrift, 98 (1), 26-35.

Zeichner, K. (2010). Rethinking the connections between campus courses and field experiences in college- and university-based teacher education. Journal of Teacher Education, 61(1-2), 89-99. 